\title{
Experimental mixing of natron and plant ash style glass: implications for ancient glass
} recycling

\author{
Scott R.B. ${ }^{1}$, Neyt B. ${ }^{1}$, Brems D. ${ }^{1}$, Eekelers, K. ${ }^{1}$, Shortland A.J. ${ }^{2}$ and Degryse P. ${ }^{1}$ \\ 1. Centre for Archaeological Sciences, Department of Earth and Environmental Sciences, KU \\ Leuven, Celestijnenlaan 200E, BE-3001 Leuven, Belgium \\ 2. Cranfield Forensic Institute, Cranfield University, Defence Academy of the United \\ Kingdom, Shrivenham, Wiltshire, SN6 8LA
}

\begin{abstract}
The practice of re-melting glass was well known, certainly from the Roman period onwards. This can be seen not only in ancient literary evidence but also in the archaeological evidence, collections of broken glass have been found in, for example, Pompeii (79AD) and the Iulia Felix shipwreck $\left(3^{\text {rd }}\right.$ century $\left.\mathrm{AD}\right)$. Elevated levels of certain transition metals in archaeological glasses are interpreted as indications of the mixing and/or recycling of different glasses. Assumptions have been made that all glasses could be recycled, but to what extent are these valid? Why does the evidence for the recycling of glass only occur from the Roman period onwards? From the middle of the $1^{\text {st }}$ millennium $\mathrm{BC}$ to the $9^{\text {th }}$ century $A D$, natron glass was the predominant glass type in the Mediterranean and Europe, however, plant ash glass was still in use in some areas. To test the effects on the final product of mixing different composition glass types, experimental glasses were made by mixing varying quantities of replica plant ash glass, replica natron glass, and a modern glass. At low temperatures crystalline material formed in the products containing replica plant ash glass. As the plant ash glass content increased, so too did the amount of crystalline material produced. This is due to a combination of the glass compositions and the firing temperature. It appears that natron type glass can be more easily recycled at lower temperatures, although, if a high enough temperature is used then most glass types can be recycled. Early furnace technology, i.e. the vertical heating chamber furnace, may not have been able to achieve these high temperatures, hence the widespread practice of recycling did not begin until after the invention of glassblowing which required a change in the furnace technology to the use of a horizontal heating chamber furnace.
\end{abstract}

\section{KEYWORDS}

Recycling; Plant Ash glass; Natron glass; Devitrification; Crystallisation

\section{INTRODUCTION}

The concept of recycling glass has long been taken for granted ${ }^{1}$, although the exact date of its discovery is unknown ${ }^{2}$. The literary evidence for recycling suggests that the discovery took place sometime in the Flavian period $\left(1^{\text {st }}\right.$ century AD) ${ }^{2}$. Writers such as Martial (Epigrams 1:41; 10:3) and Juvenal (Satires 5) mention the trade of broken glass; while Pliny the Elder ( $N H$ 36.67) says that glass can be stuck back together but never completely fused again. However, the idea that glass could be completely re-melted, did reverberate widely in Roman literature ${ }^{2,3}$. Recycling glass would have involved (re)melting waste products from glass workshops and/or old or broken glass ${ }^{1}$. The assumption that fragments of glass or cullet could be easily added to the batch has provided the basis for a number of theories seeking to explain the composition of Roman glass ${ }^{1,4-13}$. It has also been suggested that the manufacture 
of primary glass (i.e. made from raw materials) required more skill and knowledge than the production of secondary glass (i.e. worked glass), since the glass worker need only re-melt raw glass and/or cullet ${ }^{14}$. Conversely, the technical knowledge required to ensure the correct viscosity of the glass is probably one of the most important skills in glass shaping ${ }^{15,16}$.

Collections of Roman and post-Roman broken glass or cullet have been found on a variety of archaeological sites, including shipwrecks such as the $3^{\text {rd }}$ century AD Iulia Felix ${ }^{11,17}$ and in secondary glass workshops including at Bet She'an, Israel $\left(6^{\text {th }}-7^{\text {th }}\right.$ century) and in the $1^{\text {st }}$ century BC Jewish Quarter of the old city of Jerusalem ${ }^{18}$. A basket of scrap glass was found at Pompeii, which confirms that the collection of broken glass occurred prior to 79AD ${ }^{1,19}$. Finally, the chemical compositions of archaeological glasses have been used to suggest that recycling, or the reuse of old glass occurred ${ }^{1,20-26}$. This is proposed based on elevated levels of certain trace elements ( $\mathrm{Co}, \mathrm{Cu}, \mathrm{Mn}, \mathrm{Mo}, \mathrm{Ni}, \mathrm{Pb}, \mathrm{Sb}, \mathrm{Zn} . .$. ) within the glass ${ }^{4,7,20,21}$, and on the use of isotopic mixing lines ${ }^{1}$. Elevated levels of trace elements are defined as above the 'natural' level found in the raw materials ${ }^{27}$, but not high enough to constitute a deliberate addition to the glass melt. For example, if colourless glasses were being recycled and a small amount of coloured material was accidentally incorporated into the batch, this would have the effect of elevating the associated colouring elements without impacting on the colour of the glass.

Roman glass is soda-lime-silica in composition, with the majority being made from natron, a mineral soda. The use of natron glass spans the whole Roman period but was not solely limited to this era, being manufactured between the mid-first millennium $\mathrm{BC}$ and the $9^{\text {th }}$ century $\mathrm{AD}$. It is characterised by low magnesium and potassium contents $\left(\mathrm{MgO}\right.$ and $\mathrm{K}_{2} \mathrm{O}$ less than c. $1.5 \%$ ) and is sometimes referred to as LMLK glass ${ }^{7,28-30}$. A 'typical' natron glass can contain 54-74wt $\% \mathrm{SiO}_{2}, 3-8.5 \mathrm{wt} \% \mathrm{CaO}, 13-20 \mathrm{wt} \% \mathrm{Na}_{2} \mathrm{O}$ and around $2.5 \mathrm{wt} \% \mathrm{Al}_{2} \mathrm{O}_{3}{ }^{3}$. Prior to the mid-first millennium BC, a different form of flux was used in glass to lower the melting temperature of the silica. In this case, the soda content of glass originates from the use of plant ashes. Their production dates back to at least the late Bronze Age in Egypt and Mesopotamia. Due to the varying nature of the plants used in their production, their chemical composition is variable. An example of Egyptian plant ash composition glass is that from Amarna, dated to the $14^{\text {th }}$ century $\mathrm{BC}$. This glass contains on average $64.27 \mathrm{wt} \% \mathrm{SiO}_{2}$, $1.70 \mathrm{wt} \% \mathrm{Al}_{2} \mathrm{O}_{3}, 3.98 \mathrm{wt} \% \mathrm{MgO}, 8.30 \mathrm{wt} \% \mathrm{CaO}, 18.38 \mathrm{wt} \% \mathrm{Na}_{2} \mathrm{O}, 0.63 \% \mathrm{Fe}_{2} \mathrm{O}_{3}$ and $1.44 \mathrm{wt} \%$ $\mathrm{K}_{2} \mathrm{O}^{31}$. After the $9^{\text {th }}$ century $\mathrm{AD}$, there is a switch back from natron to plant ash glass, either soda-rich in the Eastern and Southern Mediterranean area, or potassium-rich in Northern Europe.

The periods of use for specific types of flux and glass are general. There would have been a certain amount of overlap between the uses of plant ash as a flux and natron. Also, not all glass manufacturers may have switched to the use of natron, some may have preferred to continue using plant ashes as a soda source ${ }^{32}$, for example, the Sassanian glasses produced between the $3^{\text {rd }}$ and $7^{\text {th }}$ centuries AD. The recycling and reuse of glass clearly occurred from the Roman period onwards. However, assumptions have been made that all glass could be recycled. This research aims at testing this assumption. What, if any, effects would the mixing of different glass compositional types have on the final product? Three different compositional types of glass, replica plant ash, replica natron glass and a modern glass (representing a generic mineral soda glass) were mixed and the chemical composition of the resulting glasses were evaluated. The mineralogical composition of devitrified, crystalline phases was also determined. 


\section{METHOD}

A replica plant ash recipe glass, i.e. a glass that had been made with modern lab grade raw materials representing a glass made with plant ash $\left(16.8 \mathrm{wt} \% \mathrm{Na}_{2} \mathrm{O}, 8.0 \mathrm{wt} \% \mathrm{MgO}, 1.0 \mathrm{wt} \%\right.$ $\mathrm{Al}_{2} \mathrm{O}_{3}, 62.3 \mathrm{wt} \% \mathrm{SiO}_{2}, 2.4 \mathrm{wt} \% \mathrm{~K}_{2} \mathrm{O}, 8.5 \mathrm{wt} \% \mathrm{CaO}, 0.4 \mathrm{wt} \% \mathrm{Fe}_{2} \mathrm{O}_{3}$ ), and a replica natron recipe glass $\left(17.4 \mathrm{wt} \% \mathrm{Na}_{2} \mathrm{O}, 1.7 \mathrm{wt} \% \mathrm{MgO}, 2.5 \mathrm{wt} \% \mathrm{Al}_{2} \mathrm{O}_{3}, 70.8 \mathrm{wt} \% \mathrm{SiO}_{2}, 0.8 \mathrm{wt} \% \mathrm{~K}_{2} \mathrm{O}, 7.0 \mathrm{wt} \%\right.$ $\mathrm{CaO}$ ) were powdered and mixed together. These replica glasses only contained the major and minor elements present in the glass, common impurities such as $\mathrm{Cl}$ or $\mathrm{S}$ were not added. A third, modern, colourless glass, (15wt $\% \mathrm{Na}_{2} \mathrm{O}, 3.2 \mathrm{wt} \% \mathrm{MgO}, 1.1 \mathrm{wt} \% \mathrm{Al}_{2} \mathrm{O}_{3}, 73.4 \mathrm{wt} \% \mathrm{SiO}_{2}$, $6.3 \mathrm{wt} \% \mathrm{CaO}$ ), was also used. The modern glass is similar in composition to a mineral soda glass, with the exception of showing higher amounts of $\mathrm{MgO}$. This is because modern manufacturers add small amounts to protect against devitrification ${ }^{33}$. Table 1 shows the varying percentages of each glass that were mixed together to create the mixed and re-molten glasses. Each glass batch was placed in a mullite crucible and then into a muffle furnace, where the temperature was raised to $900^{\circ} \mathrm{C}$. The melts were then held at this temperature for 4 hours before being allowed to cool down in the furnace. A temperature of $900^{\circ} \mathrm{C}$ was chosen because secondary glass working furnaces were operated at lower temperatures compared to primary furnaces, depending on the primary function of the furnace ${ }^{16}$. A calculation of the working and softening temperatures (http://glassproperties.com/) for each of the glass mixes used in this work indicated that $900 \mathrm{C}$ fell within working range for all of the glasses.

The compositions of the resulting glasses were determined by ICP-OES. Samples were ground to a fine powder using an agate mortar. $100 \mathrm{mg}$ was weighed and dissolved by alkaline fusion with $500 \mathrm{mg}$ of $\mathrm{LiBO}_{2}$ at $1000^{\circ} \mathrm{C}$ in graphite crucibles. The fusion was then poured into $50 \mathrm{ml}$ of $0.43 \mathrm{M} \mathrm{HNO}_{3}$ in a polypropylene beaker. The solutions were further diluted (10fold) by adding $0.43 \mathrm{M} \mathrm{HNO}_{3}$ before analysis. The compositions were determined using a Varian 720-ES equipped with a SeaSpray concentric glass nebuliser, a double-pass cyclonic glass spray chamber and a 'high solids' torch. The instrument features a Cooled Cone Interface, echelle monochromator and custom-designed Vistachip CCD detector mounted on a triple-stage Peltier device and cooled to $-35^{\circ} \mathrm{C}$. Solutions were presented to the spectrometer using the Varian SPS3 Sample Preparation System. Table 2 lists the operating parameters used for the ICP-OES analysis. The oxides determined were $\mathrm{Na}_{2} \mathrm{O}, \mathrm{MgO}, \mathrm{Al}_{2} \mathrm{O}_{3}$, $\mathrm{SiO}_{2}, \mathrm{~K}_{2} \mathrm{O}, \mathrm{CaO}, \mathrm{TiO}_{2}, \mathrm{Fe}_{2} \mathrm{O}_{3}, \mathrm{BaO}$. Calibration curves were created using solutions of four silicate-rock reference materials (GBW-7114, BR, BCS-CRM 267, BCS-CRM 269) and four glass reference materials (NIST SRM 610, NIST SRM 612, NIST SRM 620, SGT 10). Blank solutions were created by mixing the same ingredients and following the same procedure as used for the sample dissolution, but without the glass powder. BR was measured every 7 samples in order to check for possible drift of the instrumental response. Results were accurate to within $10 \%$ of the certified values for most major and minor elements, with the exception of $\mathrm{MgO}, \mathrm{TiO}_{2}$ and $\mathrm{Fe}_{2} \mathrm{O}_{3}$, these latter three were all within $20 \%$.

Some of the resulting glass samples appeared to have crystalline material present, therefore, it was decided to perform qualitative XRD analyses. Powdered samples were micronized in a McCrone Micronising mill for 5 minutes with $5 \mathrm{ml}$ ethanol as a grinding agent. After two days of drying, the samples were disaggregated in a mortar and passed through a $250 \mu \mathrm{m}$ sieve. The samples were measured with a Phillips PW180 diffractometer with a Bragg/Brentano $\theta-2 \theta$ setup and $\mathrm{CuK} \alpha$ radiation at $45 \mathrm{kV}$ and $30 \mathrm{~mA}$. The scan range was from $5-70^{\circ}$ with a step size of 0.02 and 4 seconds per step. The software used for peak identification was EVA. Thin sections were also made of each sample. 


\section{RESULTS}

Table 3 indicates the results of the ICP-OES analyses of the samples. The 'recycled' glasses all form mixing lines between the parent compositions, with the exception of $\mathrm{Na}_{2} \mathrm{O}$. In the case of the two glasses made as a result of mixing all three parent glasses, these sit within the triangle formed by the parent glasses. When the samples were removed from the furnace, all had a blue-green colour due to the iron in the original 'plant ash' glass. Several of the samples appeared crystalline in nature (Figure 1). XRD analyses indicated that sample RBS$\mathrm{D}$, made from $75 \%$ plant ash glass and $25 \%$ natron glass, had three mineral phases present quartz, combeite $\left(\mathrm{Na}_{2} \mathrm{Ca}_{2} \mathrm{Si}_{3} \mathrm{O}_{9}\right)$, augite $\left((\mathrm{Ca}, \mathrm{Na})(\mathrm{Mg}, \mathrm{Fe}, \mathrm{Al})(\mathrm{Si}, \mathrm{Al})_{2} \mathrm{O}_{6}\right)$ with the possible presence of a fourth phase in the form of pseudowollastonite $\left(\mathrm{CaSiO}_{3}\right)$. The other two plant ash/natron mixed glasses contained only three definite mineral phases (augite, quartz, combeite). In the samples made from a mix of all three parent glasses, only two mineral phases were observed (augite, quartz). A study of thin sections made from all of the samples indicated that as the amount of plant ash glass increased, so too did the amount of crystalline material in the glass (Figure 2).

\section{DISCUSSION}

Figure 2 shows that as the amount of plant ash glass is increased, the amount of crystals in the resulting glass also increases. This is a function of the glass chemistry in combination with the firing temperature used to remelt the glasses. The natron parent glass had $17.4 \mathrm{wt} \%$ $\mathrm{Na}_{2} \mathrm{O}$, and $7.0 \mathrm{wt} \% \mathrm{CaO}$, whereas the plant ash parent glass had $16.7 \mathrm{wt} \% \mathrm{Na}_{2} \mathrm{O}$ and $8.9 \mathrm{wt} \%$ $\mathrm{CaO}$. The resulting mixed glasses show a loss of $\mathrm{Na}_{2} \mathrm{O}$, compared to the predicted values (Table 4). This loss of $\mathrm{Na}_{2} \mathrm{O}$ compared to the amount of $\mathrm{CaO}$ present is not great enough on its own to cause the devitrification of the glass. However, the glasses also contain $\mathrm{MgO}$, and varying the amount of this component can have dramatic effects on both the liquidus temperature (the temperature above which all material is molten) of the melt and the subsequent formation of crystalline phases ${ }^{34}$. Likewise, varying the amount of $\mathrm{K}_{2} \mathrm{O}$ will change the viscosity of the glass and the subsequent ability of the melt to form crystalline phases ${ }^{35}$. By using a liquidus temperature calculator (http://glassproperties.com/) it was possible to determine the approximate liquidus temperature for each of the glasses used in the experiment (Table 5). The calculator models the temperature based on the common major and minor components found in soda-lime-silica glasses $\left(\mathrm{Na}_{2} \mathrm{O}, \mathrm{MgO}, \mathrm{Al}_{2} \mathrm{O}_{3}, \mathrm{SiO}_{2}, \mathrm{~K}_{2} \mathrm{O}, \mathrm{CaO}\right)$ and compares the entered values to glass from the SciGlass (www.sciglass.info) database. The database glasses all had the liquidus temperature determined experimentally. The calculated values are, however, only approximations because the $\mathrm{SiO}_{2}$ component of the glass is calculated and cannot be entered manually. These estimations show that as the amount of plant ash glass incorporated in the mix increases, so too does the liquidus temperature of the melt. It should be remembered, however, that the liquidus temperature is the point at which the total mix is molten. At lower temperatures different proportions of the batch will be in a liquid form, depending on the composition of the glass ${ }^{36-38}$.

A decrease in the temperature needed to melt the glass implies a weakening of the silicate network and a decrease in the viscosity of the glass ${ }^{39}$. In terms of glass working and the manufacture of objects, this is arguably a good thing, since it would require less fuel to operate the furnace. However, this weakening of the network increases the risk of crystallisation of the melt ${ }^{39}$. In order for crystals to form in the melt, crystal nuclei need to be present ${ }^{40}$, and these need to grow at a suitable rate ${ }^{41}$. Since the samples in this experiment were formed from existing glasses it is unlikely, although not impossible, that residual crystal 
nuclei were present in the originals. What is more likely is that the powdered nature of the samples prior to heating acted as nuclei for further crystal growth ${ }^{42}$. Since powdered particles would have been present throughout the melt and the liquidus temperature was never reached, this would explain the presence of crystal growth throughout the bulk of the samples. These results clearly show that the quantity of the crystals forming in the glasses is proportional to the amount of plant ash glass present. This is because as the amount of plant ash glass increases, the distance between the liquidus temperature of the glass and furnace temperature used increases. A study by Bingham and Marshall ${ }^{43}$ suggested minor alterations to the composition of a glass can have large effects on changes to the viscosity. They defined a key parameter in the determination of crystal formation as the difference between the 'forming' and liquidus temperatures $\left(\Delta \mathrm{T}_{\mathrm{FL}}\right)$ in the glass. The 'forming' temperature is the temperature at which the glass begins to be shaped into an object. As $\Delta \mathrm{T}_{\mathrm{FL}}$ decreases into negativity, so the risk of crystallisation increases. The forming temperatures, or the temperature at $\log 10^{4} \mathrm{~Pa}$.s (i.e. the temperature of the melt at a glass forming viscosity), for the experimental glasses were calculated using a viscosity calculator (http://glassproperties.com). The subsequent $\Delta \mathrm{T}_{\mathrm{FL}}$ for each sample was calculated (Table 5); this method also clearly shows that while the natron-rich glasses are not immune to crystallisation, the plant-ash-rich glass mixes are more likely to devitrify. XRD analyses of glasses mixed from only replica natron and modern glass indicated that no crystalline phases were present in these mixes, despite the negative $\Delta \mathrm{T}_{\mathrm{FL}}$. Some modern manufacturers give anecdotal reports of operating with negative $\Delta \mathrm{T}_{\mathrm{FL}}$ without any adverse effects, but this may be due to their furnace conditions and forming operations ${ }^{43}$.

It should be noted that glass working occurs at a range of temperatures and viscosities ${ }^{38}$ because, for example, glass blowing happens outside the furnace. The initial 'working' viscosity $\left(\log 10^{3}\right.$ Pa.s) is the point at which the melt is the correct viscosity to be gathered as a gob ready for glass forming. However, the viscosity of the glass varies during formation processes ${ }^{16}$. For example, the viscosity at the surface of a bottle during blowing was measured as being between $\log 10^{5} \mathrm{~Pa} . \mathrm{s}$ and $\log 10^{9} \mathrm{~Pa} . \mathrm{s}^{38}$. The working range of the glass is then described as being the working temperature minus the softening temperature. The smaller this number is, the shorter the working range of the glass. The temperatures needed to achieve these various viscosities are in turn dependent on the composition of the glass. While a knowledge of the working range of a glass is useful for estimating the time available for forming processes, it does not inform about the crystallisation resistance of the glass ${ }^{38}$. This is determined by the time and/or cooling rate of the melt below the liquidus temperature ${ }^{38}$. The $\Delta \mathrm{T}_{\mathrm{FL}}$ is a good indicator for the devitrification potential of a glass. However, for the study of ancient glass, the viscosity of the specific formation method, i.e. blowing, sagging, casting etc, should be used in place of the generic forming temperature.

Crystals form in a glass melt during cooling and any vitreous material which is heated for long enough above its glass transition temperature $\left(T_{g}\right)$ can crystallise ${ }^{44}$. The $T_{g}$ is the vitrification point of the melt; below the $\mathrm{T}_{\mathrm{g}}$ the material is a glass, above the $\mathrm{T}_{\mathrm{g}}$ it is molten. Nucleation of crystals usually occurs just above $T_{g}$, after processing and during cooling to a glassy state ${ }^{41}$. The nature of the crystals formed depends on the composition of the melt. The two samples which were mixed from three parent glasses had two crystalline phases (augite, quartz), the $75 \%$ plant ash and $25 \%$ natron glass had three to four crystalline phases (augite, quartz, combeite, pseudowollastonite). The remaining glass mixes had three phases (augite, quartz, combeite). Generally small additions of $\mathrm{MgO}$ and $\mathrm{Al}_{2} \mathrm{O}_{3}$ in a glass will help prevent devitrification ${ }^{33,42}$. Too much $\mathrm{MgO}$ or $\mathrm{Al}_{2} \mathrm{O}_{3}$ will, however, promote crystallisation ${ }^{45}$. Where crystals form, there is a resulting change in chemistry of the melt, depending on which 
components become bound to the structure of the crystals ${ }^{42}$. For example, silica-rich and/or alkali or alkaline-earth rich regions become more apparent ${ }^{46}$. This can lead to new crystal phases being formed through the redistribution of cations in certain areas of the silicate framework, which adjusts to their presence ${ }^{42}$.

Most of the work looking at crystal formation in archaeological glasses has occurred from the perspective of creating glass from raw batch materials rather than re-melting existing glasses. In these cases, the crystals were formed during batches fired for short periods of time and were forming from the re-crystallisation of undissolved particles in the melt ${ }^{47}$. The limit of solubility of a given element within a glass melt is governed by the temperature, therefore, crystallisation of suitable phases occurs when these limits are crossed ${ }^{48}$. For example, the maximum amount of $\mathrm{CaO}$ which can be incorporated into a typical Late Bronze Age glass was found to be c. $6 \mathrm{wt} \%$ at $900^{\circ} \mathrm{C}$ and c. $10 \mathrm{wt} \%$ at $1000^{\circ} \mathrm{C}{ }^{48}$. Previous studies have also shown that the maximum amount of $\mathrm{MgO}$ that can be incorporated into a glass melt before diopside $\left(\mathrm{CaMgSi}_{2} \mathrm{O}_{6}\right)$ crystallisation occurs is c.4-5wt\% ${ }^{48,49}$. Sample RBS-D which contained $75 \%$ plant ash glass and 25\% natron glass and RBS-PA which was a re-melt of $100 \%$ replica plant ash glass were the only samples to potentially form pseudowollastonite during cooling. However, all the glasses mixed with plant ash glass formed quartz and augite. RBS-D has $7.96 \mathrm{wt} \% \mathrm{CaO}$ and $6.08 \mathrm{wt} \% \mathrm{MgO}$. Therefore, at $900^{\circ} \mathrm{C}$, there would have been an excess of both $\mathrm{CaO}$ and $\mathrm{MgO}$ in the melt. Since augite formed, rather than diopside, this means that $\mathrm{Na}, \mathrm{Al}$ and/or Fe were also incorporated into the structure.

Studies of commercial soda-lime glasses $\left(15.90 \% \mathrm{Na}_{2} \mathrm{O} ; 0.52 \% \mathrm{~K}_{2} \mathrm{O} ; 3.63 \% \mathrm{MgO} ; 5.13 \%\right.$ $\mathrm{CaO} ; 2.17 \% \mathrm{Al}_{2} \mathrm{O}_{3}+\mathrm{Fe}_{2} \mathrm{O}_{3} ; 72.23 \% \mathrm{SiO}_{2}$ ) found quartz forming in the melt at around $862^{\circ} \mathrm{C}$ ${ }^{37}$. Similarly, Volzone and Stábile ${ }^{50}$ found a form of combeite occurring at c.800-900 $\mathrm{C}$. Combeite predominantly contains $\mathrm{Na}, \mathrm{Ca}$ and $\mathrm{Si}$, but it too can incorporate $\mathrm{Al}$ and $\mathrm{Fe}$ into its structure. The pseudowollastonite is harder to explain, since this is usually formed at higher temperatures ${ }^{51-57}$. However, Mitsuda and Banno ${ }^{58}$ accidentally formed pseudowollastonite from a mix of lime and quartz at around $200^{\circ} \mathrm{C}$. The combination of quartz crystals and excess $\mathrm{CaO}$ availability may have led to the potential production of pseudowollastonite. However, as the amount of plant ash glass is reduced, the viscosity of the resultant melt is increased, thereby making the formation of pseudowollastonite harder. The increased viscosity of the melt means it is harder for the cations to redistribute and form new crystalline phases. The $\mathrm{CaO}$ is then incorporated in other mineral phases rather than in pseudowollastonite.

It is important to note, however, that it can be extremely difficult to predict which devitrification phases will be present in a given glass, since this is dependent on the composition of the original glass, the nature of the furnace and crucibles used, the chosen furnace operating temperatures, and the speed with which the melt is subsequently cooled $37,51,59,60$. Trace level impurities in the glass can also affect the viscosity of the melt and subsequently impact on the rate of devitrification ${ }^{60}$. Likewise, increasing a minor oxide in the glass may result in the precipitation of a multi-element phase ${ }^{59}$. In essence, if a glass melt is held at a temperature favourable to crystal development for long periods of time, then this glass is likely to devitrify. This temperature changes depending on the composition of the melt ${ }^{35}$.

\section{Archaeological Implications}


Previous work, which compared natron and plant ash glass compositions, found that the earlier plant ash glasses formed around the soda-rich cotectic. The silica-rich cotectic is favoured by natron glass ${ }^{61}$. This means that plant ash glasses can be made using shorter firing times with less fuel requirements ${ }^{61}$. In terms of the current research, where the focus is on the mixing of different glass compositions, the results clearly show that natron composition glass can be remelted more successfully than plant ash glass at $900^{\circ} \mathrm{C}$. From the work of Shugar and Rehren ${ }^{61}$, Van Beeumen ${ }^{62}$, Bingham and Jackson ${ }^{63}$ and others, it is clear that Roman primary glass furnaces would have had temperatures capable of re-melting all types of glass cullet. However, the success of this would be partially dependent on the amount of cullet used and what proportions of that cullet were of different compositions. As Freestone ${ }^{28}$ suggests, if glass recycling occurred on an intra-regional basis, then the glasses being mixed were likely to be of the same basic type. The incorporation of plant ash glass cullet to a natron type raw batch would almost certainly result in a degree of crystallisation. However, if only a small amount of plant ash cullet were used, then it may have been possible, if necessary, to pick out the devitrified pieces when the raw glass was broken up. The higher temperatures in the majority of the tank furnace may also have resulted in less devitrification, but this remains to be modelled. It is more likely that crystallisation would still occur, but the nature of the crystals may vary, for example, at between $800^{\circ} \mathrm{C}$ and $1100^{\circ} \mathrm{C}$ wollastonite $\left(\mathrm{BCaSiO}_{3}\right)$ is known to form ${ }^{64}$. The absence of wollastonite in our samples is due to the low temperature used for firing, although pseudowollastonite phases did occur as the plant ash glass content increased.

In terms of secondary glass working, natron glass could be re-melted and recycled either on its own or as part of a mixed batch. The nature of the working furnace would have played a significant role in terms of whether the glass could or could not be successfully recycled. For example, the early furnaces with a vertical heating chamber achieved a lower temperature, whereas the later horizontal heating chamber furnaces allowed glass workers to use molten glass $^{2}$. At lower temperatures, mixing glass compositions may have created some problems in terms of devitrification and the removal of bubbles, but it would certainly have been possible to recycle the glass. The main crystalline phases forming in the three glass mixes were augite and quartz, but of this, the amount of crystalline material was greatly reduced when the amount of incorporated plant ash glass was reduced. Freestone et al ${ }^{65}$ analysed some Anglo-Saxon period glasses which appeared to be a mix of both natron and plant ash material. They concluded that these $6^{\text {th }}$ century AD glasses were more likely natron glasses with the addition of a quantity of plant ash material to extend a restricted supply of glass, rather than the mixing of natron glass and plant ash glass. However, around the $6^{\text {th }}$ century $\mathrm{AD}$, attempts could have been made to extend the available natron glass by the addition of up to $10 \%$ plant ash glass ${ }^{65}$. It should be noted however, that the composition of the later plant ash glasses would be different again to that used in this study. Therefore, even if devitrification did occur when natron glass was recycled, it probably happened to a relatively small degree. The glass mix itself could still be worked although the final glass product may have had flaws. "Like the Roman glassblower's furnace, furnaces in Herat (Afghanistan), Damascus, Hebron, and Cairo still functioning in the 1960s and 1970s remelted broken glass, but the quality of their output was poor. The glass is bubbly and full of striae and other impurities, in part because they did not achieve the high temperatures required for complete fusion" (Stern, 1999: 451-452).

Late Bronze Age plant ash glass would have been difficult to recycle in secondary furnaces. In very small quantities, this may have been possible, but would probably have been detrimental to the final product. It could have been possible to refine the results of plant ash- 
rich glass mixes and improve the amount of glassy material collected (as has been demonstrated in other research ${ }^{61}$ ), but this would have required time, fuel and resources. What may be more probable is that small amounts of plant ash glass were, if at all, recycled as cullet added in the glass making stage, where fresh mineral matter and plant ashes are molten. The composition of the early plant ash glass is such that it could not be worked and re-melted in the same way as natron glass. The increased $\mathrm{K}_{2} \mathrm{O}$ in plant ash glass will increase the viscosity of the melt and thereby reduce the workability of the glass ${ }^{35}$. An important modern observation on the use of cullet in glass manufacture is that as the composition of the cullet varies, so too will its effect on the final glass. Therefore, batch calculations are necessary to compensate for the compositional difference ${ }^{43}$. Late Bronze Age and Early Iron Age glass was also strongly coloured. Therefore, unless the glass was well sorted, any attempt to remelt it would probably result in a dark or black glass. Early attempts to completely re-melt glass may have failed and/or resulted in a devitrified product, possibly even with an unappealing colour. This in turn would have led people to believe that glass cannot be re-melted or reused. As natron glass came into use, waste from glass manufacture could be included and reused, encouraging people to again try recycling broken glass.

Late Bronze Age plant ash glass was prone to devitrification when re-melted. The increased risk of crystallisation coupled with the shorter working ranges of plant ash glass could indicate why the invention of glass blowing and recycling may not have occurred until after natron glass became the predominant type. The subsequent use of horizontal heating chamber furnaces, coupled with the variation in plant ash glass compositions, meant it eventually became possible for plant ash glasses themselves to be recycled. This is evidenced by the analysis of glasses from later periods, where sodic and potash glass has been mixed and recycled ${ }^{32,66}$. The discovery that glass could be recycled would, as Stern ${ }^{2}$ puts it, have been revolutionary. Yet, the speed and extent to which this new idea spread would have been dependent on political, economic and local factors. Since a small change in the composition of the glass could potentially have had a very dramatic effect on the properties and workability of the glass, artisans may have been cautious. In areas where only one type or composition of glass was in use, the concept of recycling may have spread very quickly. The benefits of recycling old glass, such as the reduction of fuel consumption, may well have outweighed the risks involved. In other areas, at the frontiers of glass types, the adoption of the idea of recycling may have been accepted more gradually.

\section{CONCLUSION}

The widespread belief that glass in the Roman period was recycled lead to the general assumption that all glass could be recycled. While it is true that if a high enough temperature is reached (as would probably have happened in tank furnaces during primary glass manufacture), then most types of glass can be incorporated as cullet into a large batch. The inclusion of plant ash glass cullet in remelting a batch of natron glass, however, could have detrimental effects. In low quantities this may have been a negligible issue, but as the amount of plant ash glass used was increased, so too did the risk of devitrification increase. Natron glass, as such, could be recycled and reused. However, with early furnace technology, plant ash glass could not. It is most likely that 'old' glass or cullet would have been used as pieces or chunks of glass, since powdering would have created the nuclei necessary for crystallisation to occur. Yet, even in glass form, the composition of natron glass does not preclude it from devitrifying during recycling and subsequent manufacture. Mixing plant ash glass in with natron glass recycling would lead to increased crystal formation. The nature of this process would be determined partly by the composition of the melt and partly by the 
temperature of the furnace. The horizontal heating chamber furnace used for glass blowing, which enabled the melt to stay hotter for longer, was invented in the $1^{\text {st }}$ century BC. Prior to this glass workers may not have been able to maintain a high enough temperature to ensure a crystal free melt. This may explain why the discovery that glass could be completely remelted and therefore recycled did not occur until relatively late (c. $1^{\text {st }}$ century AD). The nature, amount and rate of crystal growth is dependent on a number of variables including melt composition, liquidus temperature, forming temperature, $\Delta \mathrm{T}_{\mathrm{FL}}$, furnace temperature, crucible composition and cooling rate. Therefore, evidence of glass recycling in antiquity is testament to the skills and technical knowledge of the glass workers.

\section{Acknowledgements}

The authors would like to thank Herman Nijs for the production of the thin sections, Steven Luypaers for the ICP-OES analysis and Adrian Mustey for operating the muffle furnace. The research was funded by the ERC Starting Grant ARCHGLASS Grant agreement no. 240750. Dieter Brems is currently working as postdoctoral fellow of the Research Foundation Flanders (FWO-Vlaanderen). 
Table 1: The percentages of the powdered glasses mixed together to form the new melts.

Table 2: Operating parameters of the ICP-OES.

Table 3: The results of the ICP-OES analyses of the samples, reported in wt\%.

Table 4: The predicted compositions of the glasses mixed with plant ash glass in wt $\%$.

Table 5: The liquidus temperatures and viscosity temperatures of the glasses determined using the liquidus temperature calculator and the viscosity calculator (http://glassproperties.com/). The modelled and actual $\mathrm{SiO}_{2}$ values are also listed in $\mathrm{wt} \%$. The $\Delta \mathrm{T}_{\mathrm{FL}}$ and working range for each glass is also shown.

Figure 1: Sample RBS-D (75\% plant ash glass, $25 \%$ natron glass) indicating the crystalline phases present. Left: plain polarised light, $5 \mathrm{x}$ magnification; right: plain polarised light, 20x magnification.

Figure 2: Thin sections of the glass indicating the increasing volume of crystals in relation to the increasing amount of plant ash glass in the melt. All glasses are shown in plain polarised light at 5x magnification. From left to right and from top to bottom (RBS-H 10\% PA; RBS-C 25\% PA; RBS-G 33\% PA; RBS-F 50\% PA; RBS-D 75\% PA; RBS-PA 100\% PA). 


\section{REFERENCES}

1. Degryse P, Schneider J, Haack U, et al. Evidence for glass "recycling" using $\mathrm{Pb}$ and $\mathrm{Sr}$ isotopic ratios and Sr-mixing lines: the case of early Byzantine Sagalassos. J Archaeol Sci. 2006;33:494-501.

2. Stern EM. Roman Glassblowing in a Cultural Context. Am $J$ Archaeol. 1999;103(3):441-484.

3. Arletti R, Ciarallo A, Quartieri S, Sabatino G, Vezzalini G. Archaeometric analyses of game counters from Pompeii. In: Maggetti M, Messiga B, eds. Geomaterials in Cultural Heritage. Geological. London: The Geological Society of London; 2006:175186.

4. Degryse P, Shortland A. Trace Elements in Provenancing Raw Materials for Roman Glass Production. Geol Belgica. 2009;12(3-4):135-143.

5. Aerts A, Janssens K, Adams F, Wouters H. Trace-Level Microanalysis of Roman Glass from Khirbet Qumrân, Israel. J Archaeol Sci. 1999;26:883-891.

6. Aerts A, Velde B, Janssens K, Dijkman W. Change in silica sources in Roman and post-Roman glass. Spectrochim Acta Part B. 2003;58:659-667.

7. Wedepohl KH, Simon K, Kronz A. Data on 61 Chemical Elements for the Characterisation of Three Major Glass Compositions in Late Antiquity and the Middle Ages. Archaeometry. 2011;53(1):81-102.

8. Silvestri A, Molin G, Salviulo G. Roman and Medieval Glass from the Italian Area: Bulk Characterisation and Relationships with Production Technologies. Archaeometry. 2005;47(4):797-816.

9. Silvestri A, Molin G, Salviulo G, Schievenin R. Sand for Roman Glass Production: An Experimental and Philological Study on Source of Supply. Archaeometry. 2006;48(3):415-432.

10. Antonaras AC. Early Christian and Byzantine Glass Vessels: Forms and Uses. In: Daim F, Drauschke J, eds. Byzanz - das Römerreich im Mittelalter Teit 1 Welt der Ideen, Welt der Dinge. Germany: Der Deutschen Nationalbibliothek; 2010:383-428.

11. Silvestri A. The coloured glass of Iulia Felix. J Archaeol Sci. 2008;35:1489-1501.

12. Foster HE, Jackson CM. The composition of "naturally coloured" late Roman vessel glass from Britain and the implications for models of glass production and supply. $J$ Archaeol Sci. 2009;36:189-204.

13. Freestone IC. Primary Glass Sources in the Mid First Millennium AD. In: Annales du 15e Congrès de l'Association Internationale pour l'Histoire du Verre (AIHV). USA; 2001:111-115.

14. Van der Linden V, Cosyns P, Schalm O, et al. Deeply Coloured and Black Glass in the Northern Provinces of the Roman Empire: Differences and Similarities in Chemical Composition Before and After AD 150. Archaeometry. 2009;51(5):822-844.

15. Fluegel A. Glass viscosity calculation based on a global statistical modelling approach. Glas Technol Eur J Glas Sci Technol Part A. 2007;48(1):13-30.

16. Stern EM. Roman Mold-blown Glass: The First Through Sixth Centuries. Italy: "L'Erma" di Bretschneider; 1995.

17. Longinelli A, Silvestri A, Molin G, Salviulo G. 1.8ka old glass from the Roman ship 
"Julia Felix": glass-water oxygen isotope exchange. Chem Geol. 2004;211:335-342.

18. Gorin-Rosen Y. The Ancient Glass Industry in Israel: Summary of the finds and new discoveries. In: Nenna MD, ed. La Route du Verre. Lyon: Travaux de la Maison de l'Orient Méditerranéen No. 33; 2000:49-63.

19. Morel JP. La ceramica e il vetro. In: Zevi F, ed. Pompei 79. Naples: Gaitano Macchiaroli; 1979:241-264.

20. De Francesco AM, Scarpelli R, Barca D, Ciarallo A, Buffone L. Preliminary chemical characterisation of Roman glass from Pompeii. Period di Mineral. 2010;79(3):11-19.

21. Baxter MJ, Cool HEM, Jackson CM. Further Studies in the Compositional Variability of Colourless Romano-British Vessel Glass. Archaeometry. 2005;47(1):47-68.

22. Aerts A, Janssens K, Velde B, Adams F, Wouters H. Analysis of the Composition of Glass Objects from Qumrân, Israel. In: Nenna MD, ed. La Route du Verre. Lyon: Travaux de la Maison de l'Orient Méditerranéen No. 33; 2000:113-121.

23. Nenna MD, Picon M, Vichy M. Ateliers Primaires et Secondaires en Égypte à l'Époque Gréco-Romaine. In: Nenna MD, ed. La Route du Verre. Lyon: Travaux de la Maison de l'Orient Méditerranéen No. 33; 2000:97-112.

24. Paynter S. Analyses of colourless Roman glass from Binchester, County Durham. $J$ Archaeol Sci. 2006;33:1037-1057.

25. Freestone IC. The Provenance of Ancient Glass through Compositional Analysis. Mater Res Soc Symp Proc. 2005;852:008.1.1-008.1.14.

26. Arletti R, Vezzalini G, Benati S, Mazzeo Saracino L, Gamberini A. Roman Window Glass: A Comparison of Findings from Three Different Italian Sites. Archaeometry. 2010;52(2):252-271.

27. Brems D, Degryse P. Trace Element Analysis in Provenancing Roman Glass-Making. Archaeometry. 2014;56(Suppl. 1):116-136.

28. Freestone IC. Glass production in Late Antiquity and the Early Islamic period: a geochemical perspective. In: Geomaterials in Cultural Heritage. Geological Society of London, Special Publications 257.Vol 257.; 2006:201-216.

29. Henderson J. The raw materials of early glass production. Oxford J Archaeol. 1985;4:267-291.

30. Sayre EV, Smith RW. Compositional Categories of Ancient Glass. Science (80- ). 1961;133(3467):1824-1826.

31. Moretti C, Hreglich S. Raw Materials, Recipes and Procedures Used for Glass Making. In: Janssens K, ed. Modern Methods for Analysing Archaeological and Historical Glass. Chichester: John Wiley and Sons Ltd.; 2013:23-47.

32. Gratuze B. Provenance Analysis of Glass Artefacts. In: Janssens K, ed. Modern Methods for Analysing Archaeological and Historical Glass. Chichester: John Wiley and Sons Ltd.; 2013:311-343.

33. Shelby JE. Introduction to Glass Science and Technology. 2nd . Cambridge: Royal Society of Chemistry; 2005.

34. Shahid KA, Glasser FP. Phase equilibria in the glass forming region of the system Na2O-CaO-MgO-SiO2. Phys Chem Glas. 1972;13(2):27-42.

35. Bowen NL. Devitrification of Glass. J Am Ceram Soc. 1919;2(4):261-281. 
36. Zhang Z, Xiao Y, Voncken JHL, et al. Phase equilibria in the CaO.SiO2-Na2O.SiO2Na2O.A12O3.6SiO2 system. J Eur Ceram Soc. 2014;34:533-539.

37. Morey GW. The effect of alumina on the devitrification of a soda-lime-silica glass. $J$ Am Ceram Soc. 1930;13(10):718-723.

38. Wallenberger FT, Smrček A. The Liquidus Temperature; Its Critical Role in Glass Manufacturing. Int J Appl Glas Sci. 2010;1(2):151-163.

39. Fernández-Navarro JM, Villegas MA. What is Glass? In: Janssens K, ed. Modern Methods for Analysing Archaeological and Historical Glass. Chichester: John Wiley and Sons Ltd.; 2013:1-22.

40. Varshneya AK. Fundamentals of Inorganic Glasses. Sheffield: Society of Glass Technology; 2006.

41. Biron I, Chopinet MH. Colouring, Decolouring and Opacifying of Glass. In: Janssens K, ed. Modern Methods for Analysing Archaeological and Historical Glass. Chichester: John Wiley and Sons Ltd.; 2013:49-65.

42. Aboud TK, Stoch L, Środa M. Quartz crystallisation in soda-lime-silica glass. Opt Appl. 2005;35(4):829-836.

43. Bingham PA, Marshall M. Reformulation of container glasses for environmental benefit through lower melting temperatures. Glas Technol. 2005;46(1):11-19.

44. Fokin VM, Potapov OV, Zanotto ED, Spiandorello FM, Ugolkov VL, Pevzner BZ. Mutant crystals in Na2O.2CaO.3SiO2 glasses. J Non Cryst Solids. 2003;331:240-253.

45. Wallenberger FT, Hicks RJ, Bierhals AT. Design of environmentally friendly fiberglass compositions: ternary eutectic $\mathrm{SiO} 2-\mathrm{Al} 2 \mathrm{O} 3-\mathrm{CaO}$ compositions, structures and properties. J Non Cryst Solids. 2004;349:377-387.

46. Cormier L, Calas G, Beuneu B. Structural changes between soda-lime silicate glass and melt. J Non Cryst Solids. 2011;357:926-931.

47. Paynter S. Experiments in the Reconstruction of Roman Wood-Fired Glassworking Furnaces: Waste Products and Their Formation Processes. J Glass Stud. 2008;50:271290.

48. Rehren T. A review of factors affecting the composition of early Egyptian glasses and faience: alkali and alkali earth oxides. J Archaeol Sci. 2008;35(5):1345-1354. doi:10.1016/j.jas.2007.09.005.

49. Morey GW. The Effect of Magnesia on the Devitrification of a Soda-Lime-Silica Glass. J Am Ceram Soc. 1930;13(10):714-717.

50. Volzone C, Stábile FM. Structural Changes by Thermal Treatment up to Glass Obtention of P2O5-Na2O-CaO-SiO2 Compounds with Bioglass Composition Types. New J Glas Ceram. 2013;3:53-57.

51. Salman SM, Salama SN, Abo-Mosallam HA. The crystallization behaviour and bioactivity of wollastonite glass-ceramic based on Na2O-K2O-CaO-SiO2-F glass system. J Asian Ceram Soc.

52. Omar AA, Abdel-Hameed SAM. Crystallization of calcium zinc aluminosilicate glasses. Ceram - Silikáty. 2009;53(3):171-179.

53. Salman SM, Salama SN, Abo-Mosallam HA. Crystallization behaviour and properties of multicomponent strontium - Containing lithia calcia silicate glasses. Ceram Int. 2010;36:2307-2314. 
54. Richet P, Robie RA, Hemingway BS. Thermodynamic properties of wollastonite, pseudowollastonite and CaSiO3 glass and liquid. Eur J Mineral. 1991;3:475-484.

55. Yang H, Prewitt CT. On the crystal structure of pseudowollastonite (CaSiO3). Am Mineral. 1999;84:929-932.

56. Jeffery JW, Heller L. Preliminary X-ray investigation of pseudo-wollastonite. Acta Crystallogr. 1953;6:807-808.

57. Courtial P, Téqui C, Richet P. Thermodynamics of diopside, anorthite, pseudowollastonite, $\mathrm{CaMgGeO} 4$ olivine, and akermanite up to near the melting point. Phys Chem Miner. 2000;27:242-250.

58. Mitsuda T, Banno S. Hydrothermal Formation of Pseudowollastonite from LimeQuartz Mixtures at 165o and 200oC. Cem Concr Res. 1977;7:457-460.

59. Rehren T. Ramesside Glass-Colouring Crucibles. Archaeometry. 1997;39(2):355-368.

60. Bihuniak PP. Effect of Trace Impurities on Devitrification of Vitreous Silica. Commun Am Ceram Soc. 1983:C188-C189.

61. Shugar A, Rehren T. Formation and composition of glass as a function of firing temperature. Glas Technol. 2002;43C:145-150.

62. Van Beeumen R. Numerical Modelling of Primary Glass Furnaces in the 1st Millenium AD. 2010.

63. Bingham PA, Jackson CM. Roman blue-green bottle glass: chemical-optical analysis and high temperature viscosity modelling. J Archaeol Sci. 2008;35:302-309.

64. Schairer JF, Bowen NL. The binary system CaSiO3-diopside and the relations between CaSiO3 and akermanite. Am J Sci. 1942;240(10):725-742.

65. Freestone IC, Hughes MJ, Stapleton CP. The Composition and Production of AngloSaxon Glass. In: Evison VI, ed. Catalogue of Anglo-Saxon Glass in the British Museum. London: The Trustees of the British Museum; 2008:29-46.

66. Velde B. Glass Compositions over Several Millennia in the Western World. In: Janssens K, ed. Modern Methods for Analysing Archaeological and Historical Glass. Chichester: John Wiley and Sons Ltd.; 2013:67-78. 